\title{
Spatial distribution pattern of Tarsius Lariang in lore lindu national park
}

\author{
Abdul Rosyid ${ }^{1}$, Yanto Santosa ${ }^{2}$, I Nengah Surati Jaya ${ }^{3}$, M. Bismark ${ }^{4}$, Agus P. Kartono ${ }^{5}$ \\ ${ }^{1}$ Department of Forestry, Faculty of Forestry, Tadulako University, Kota Palu, Sulawesi Tengah, Indonesia \\ ${ }^{2,5}$ Department of Forest Resources Conservation and Ecotourism, Faculty of Forestry, \\ Bogor Agricultural University, Indonesia \\ ${ }^{3}$ Department of Forest Management, Faculty of Forestry, Bogor Agricultural University, Indonesia \\ ${ }^{4}$ Forest Research and Development Center, Bogor, Indonesia
}

\begin{tabular}{l} 
Article Info \\
\hline Article history: \\
Received May 21, 2018 \\
Revised Sep 13, 2018 \\
Accepted Nov 25, 2018 \\
\hline
\end{tabular}

\section{Keywords:}

Cluster analysis

Dendrogram

Environmental affecting factor

Spatial distribution pattern

Tarsius lariang

\begin{abstract}
Tarsius lariang (T. lariang) is an endemic species in Lore Lindu National Park (LLNP). Available information regarding T. lariang is limited to only morphological, anatomical, cytogenetic, and voices issues. Knowledge for its geospatial characteristics such as spatial preferences and spatial distribution is rare. The main objective of this study is to identify the spatial distribution pattern of T. lariang in LLNP. An additional objective is to identify the environmental factors affecting its spatial distribution patterns. Field observation for distribution pattern was done at the observation plot that were using systematic sampling with random start. Furthermore, the density estimation in each point was calculated using Triangle Count and Concentration Count method, while insect abundance was estimated using light traps sample data. Finally, spatial pattern was estimated using nearest neighbor index, while the environmental affecting factors were identified by using spatial analysis and correlation analyses. From 45 observation points, the T. lariang distribution pattern was clumped. It is also recognized that the significant factors affecting the spatial distribution were insect abundance, proximity from the commercially utilized land, and land surface temperature.
\end{abstract}

Copyright $(2019$ Institute of Advanced Engineering and Science. All rights reserved.

\section{Corresponding Author:}

I Nengah Surati Jaya,

Department of Forest Management,

Faculty of Forestry, Bogor Agricultural University,

Darmaga, Bogor 16680, Indonesia.

Email: ins-jaya@apps.ipb.ac.id

\section{INTRODUCTION}

The Lore Lindu National Park (LLNP) is one of the most important tropical rain forest conservation areas located in the eastern part of Indonesia. Geographically, the LLNP is located within the Wallacea region that blending Asian and Australian flora fauna has high species endemicity. Tarsius lariang (T. lariang) is one of the endemic animals found in LLNP which has the smallest body size compared to other primate species $[1,2]$. There are three species of T. lariang in the TNLL, i.e., T. pumilus, T. dentatus and T. lariang. Based on a series of morphological, anatomical, cytogenetic, and voice research in 2006 [1], T. lariang was recognized as a "new primate species from western Central Sulawesi" [1].

The recognition of $T$. lariang as a new species has been very important step for its conservation. According to the IUCN [3], currently the status of the conservation of T. lariang is "data deficient" or lack of data. Up to now, no scientific publication has been found related to geospatial information of $T$. lariang in LLNP, while the information about $T$. lariang is crucial in this area. So far, the available research on $T$. lariang outside of TNLL has been reported in 2006 [1], however, the study is limited only on the morphological, anatomical, cytogenetic, as well as voices. Another issue that also should be considered in the area, is the 
pressure that the national park has from various land utilization, such as land for coffee and cocoa plantations, bamboo and rattan collection activities, which may affect the status of $T$. lariang population.

By considering the above issues, efforts for conserving the $T$. lariang have been undertaken through appropriate conservation programs, collecting information on distribution patterns as well as the environmental factors like habitat preference of T. lariang. The utilization of spatial knowledge, i.e., geospatial information system (GIS) in various fields of natural resource management has been widely applied, particularly by using various spatial modeling [4-8]. Now, the GIS technology has been proven as effective tools and methods to monitor management activities, analysis and visualization of wild animal's data, including habitat requirements and ranges, population patches and linkages, disease levels within populations, progress of management activities and historical and present wildlife densities [9].

In this study, the GIS technology was applied for estimating the spatial characteristics and analyzing the spatial pattern of $T$. lariang in TNLL, by integrating the spatial capability analysis of GIS software and field-based data inventory. The main objective of the study is to identify the spatial distribution and spatial pattern of T. lariang in TNLL, while the additional objective is to identify the environmental factors affecting its distribution pattern. The environmental factors considered were biophysical and anthropogenic factors.

\section{RESEARCH METHOD}

\subsection{Date and Site}

The field data collection was conducted from April 2011 to March 2012 within a part of the TNLL area. Research data was located within the working area of Toro and Moa resorts.The area is located within Kulawi and Southern Kulawi, Sigi and Poso Regencies Central Sulawesi Province.

\subsection{Tools, Software, Hardware, and Data}

For Field data collection, the equipments used were global positioning system (GPS) tracking device, clinometer, and altimeter. For insect observation, the study used light trap, white cotton fabric $3 \mathrm{~m}$ long and width $2 \mathrm{~m}$, and ethyl acetate. The spatial analysis was carried out using ArcGIS version 10.1. The main spatial data was Landsat Thematic Mapper (TM) image path 114 / row 61 of 2011; while the supporting data include administrative maps, LLNP area maps, contour maps and Indonesian landform map at a scale 1: 250,000 sheets 2014-64 (Maranata), 2114-43 Kamarora, 2014-62 (Kulawi), 2114-41 (Langko), 2114-42 (Wuasa), 2114-13 (Lawua), 2114-14 (Doda), and 2114-11 (Gintu); boundary map of TNLL forest area.

\subsection{Data Collection and Analysis 2.3.1 Data Collection}

$T$. lariang distribution data was collected through field surveys by exploring areas of $T$. lariang concentration in various habitat types. The sample unit of observation was laid out by using systematic sampling with random start with $1 \mathrm{~km} \mathrm{x} 1 \mathrm{~km}$ interval, processed spatially using extension IHMB version.34 [10]. Each direct encounter of $T$. lariang was recorded in habitat type and linked with other data such as temperature, humidity, slope, altitude and its geographic coordinates using the GPS tracking device. Data collection for relative density of individual population of $T$. lariang was done by using Triangle Count and Concentration Count $[11,12]$. The calculation of relative density of individual $T$. lariang was using the formula developed by O'Brien and Duma $[13,14]$. The calculation of the abundance of insects was done by trapping insects at each point of $T$. lariang encounter. Trapping insects was done by using a light trap. For analysis, the considered insects were those only have a body length longer than $>1 \mathrm{~cm}$.

\subsection{Data Analysis}

\subsubsection{Identification of $\boldsymbol{T}$. lariang concentration area}

Spatial distribution of $T$. lariang was obtained based on the number of individuals encountered in the field, by marking the geographic coordinate using GPS tracker. Furthermore, the spatial distribution and the concentration area of $T$. lariang were analyzed using Inverse Distance Weigted (IDW), interpolation method available in ArcGis version 10.1. The result of T. lariang density interpolation was used later on, as the basis for determining the location spatial pattern and identifying the affecting environmental factors.

\subsubsection{T. lariang spatial distribution pattern}

Spatial distribution patterns were analyzed to determine the relationship between the distribution of T. lariang and the factors that might affect it.The method used in estimating spatial distribution pattern was Nearest Neighbor Index (NNI), calculated by using the following formula: 


$$
N N I=\frac{D O}{D E} ; \mathrm{DO}=\frac{\sum_{i=1}^{n} d i}{N} ; D E=\frac{0.5}{\sqrt{\frac{N}{A}}}
$$

DO is Observed Distance, while DE is the Expected Distance. The spatial distribution pattern will be categorized as clumped when the $\mathrm{NNI}<1$; as random when the $\mathrm{NNI} \approx 1$; and as dispersed (uniform) when the NNI $>1[15,16]$.

\subsubsection{Environmental factors affecting the spatial pattern}

The environmental factors considered in this study include proximity from settlement, commercial areas (cacao, coffee, and mixed garden), and proximity from the road. Those factors were derived from the spatial operation using the GIS software for obtaining spatial distribution of the insect abundance, then the IDW was applied. The statistical parameters for each environmental factor are summarized in Table 1.

Table 1. Environmental factors and disturbance area used in analysis

\begin{tabular}{lrrrr}
\hline \multicolumn{1}{c}{ Environmental factors } & Minimum & Maximum & Total data & Interval \\
\hline Insect abundance (ind/hour/ $\left.\mathrm{km}^{2}\right)$ & 1.1 & 63.4 & 80 & 0.8 \\
Distance from road (m) & 50 & 7300 & 138 & 53 \\
Distance from settlement area (m) & 100 & 7300 & 73 & 99 \\
Distance from commercial area (m) & 100 & 4800 & 48 & 98 \\
Altitude (asl) & 369 & 1653 & 42 & 30.6 \\
Slope (\%) & 1 & 52 & 36069 & 0 \\
Temperature $\left({ }^{\circ} \mathrm{C}\right)$ & 22.5 & 27.1 & 93 & 0.05 \\
Humidity $(\%)$ & 77.2 & 86.0 & 102 & 0.09 \\
\hline
\end{tabular}

\subsubsection{Determination of environmental factors on spatial patterns}

For selecting the most affecting factors, the study analyses the correlation among the dependent variable (density of $T$. lariang) and all the independent variables (environmental factors) as mentioned above. The steps for selecting the most significant variables are as follows:

1. All independent variables, i.e. abundance of insects (X1), distance from road (X2), distance from settlement (X3), distance from commercial area (X4), elevation (X5), slope (X6), temperature (X7), and the humidity (X8) were examined.

2. All variables except insect abundance (X1) were examined. The $\mathrm{X} 1$ is excluded since this variable is relatively difficult to obtain.

3. Insect abundance (X1), commercially unit areas (X4), and temperature (X7) where examined due to their close correlation with the density of $T$. lariang.

4. Variable distance from commercial area (X4) and temperature (X7) were examined. These two variables are easily derived from the existing remote sensing technology and considered to have a high correlation with the density of $T$. lariang.

5. Only variable insect abundance (X1) was examined. This to assess the capability of this variable to estimate the spatial distribution pattern of $T$. lariang.

These variables were used to classify the density of $T$. lariang using the clustering method, where the dendogram was developed using the complete linkage algorithm.

\section{RESULTS AND ANALYSIS}

\subsection{Location identification of $\boldsymbol{T}$. lariang spatial distribution area}

From the 45 observation points of $T$. lariang, in Figure 1, the study shows that $T$. lariang is distributed in transitional areas between primary and secondary forest. This indicates that $T$. lariang is the edge species animal. High abundance of insect feeds in edge area or ecotone has been closely correlated with the density of T. lariang. This is in line with the study of Mansyur et. al. [17] that T. tarsiers in the Lambusango Forest of Buton Island are found in the forest edge area habitats.

The edge forest area has a unique microhabitat vegetation structure with more vegetative species and more seedlings [18, 19]. Low canopy cover on these edges causes an increment in insect-feed biomass [19]. From the spatial data of the location and density of $T$. lariang, the spatial analysis shows that spatial distribution pattern of $T$. lariang in LLNP is clumped with NNI $=0.2$ or $<1$. The spatial distribution pattern of $T$. lariang is related to its behaviour to maintain its survival, and closely related to environmental conditions, such as biophysical and anthropogenic factors. This clumped distribution of $T$. lariang might be influenced by its 
behaviour, as territorial animal, competing with other Tarsius species, such as $T$. dentatus. Homogeneity of habitat, and other factors (such as prey, biomass-feed, and other suitable factors) are also suspected in affecting the spatial distribution of T. lariang [19-21].

Most of the field observation points belong to the primary forest (40 points) while only a few points (5 points) belongs into secondary forest. Primary forest has a good quality for habitat of T. lariang. In primary forest land cover, there are many ficus sp. trees and large trees that have holes for shelter and rest, whereas secondary forests are preferred as feeding places. This case was similar to the T.tarsier, found in TangkokoBatu Angus Nature Reserve area of North Sulawesi, that uses ficus spp tree as its nest [22]. Other allegations that cause spatial distribution of clustered T. lariang are kinship, gregarious behavior, similarity of interest in the utilization of resources (feed and space) and anti-predator [23].

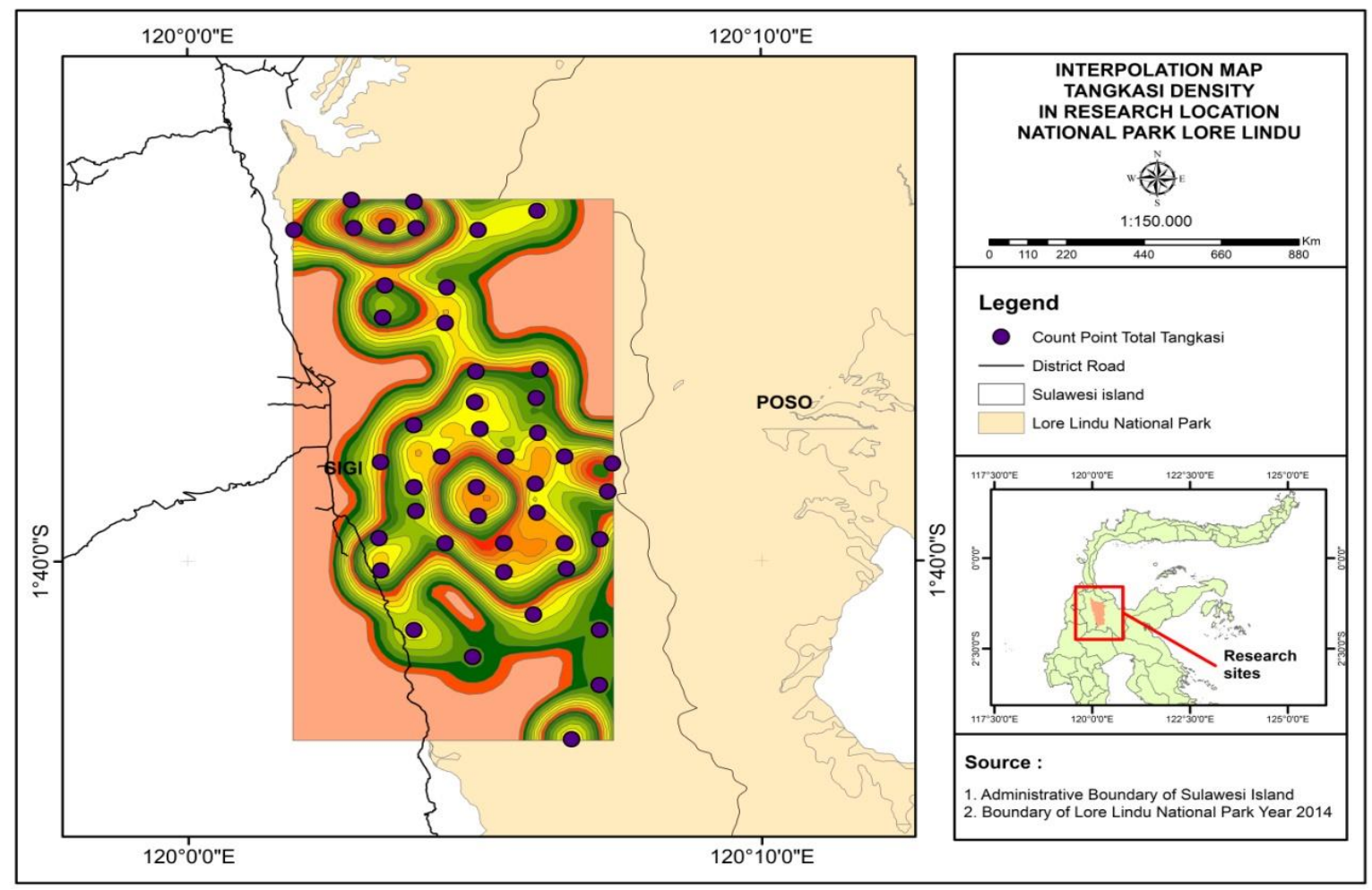

Figure 1. Spatial distribution of T. lariang developed using IDW interpolation result in Lore Lindu National Park

\subsection{The environmental variables that influence spatial distribution pattern of $T$. lariang}

Based on the results of analysis, there are 7 variables that have high contribution to the spatial distribution pattern of $T$. lariang. They are the abundance of insects, followed by the distance to commercially utilized area, humidity, temperature, distance from the road, distance to settlement and altitude. Slope variable within the study area do not significantly contribute in the spatial distribution pattern of $T$. lariang, having very small $\mathrm{R}^{2}$ value of only $32.3 \%$.

\subsubsection{Correlation of $\boldsymbol{T}$. lariang density with source of feed}

Tarsius is a small primate which is classified to the first primitive insectivore category that makes the staple food $[24,25]$. Tarsius uses hearing sensors to catch insects from their rustling voices and flutter of its wings [25, 26]. Tarsius takes 58--141 grams of insects per day to meet their feeding needs [27]. The result of the analysis in Figure 2, shows that there is a very close correlation between density of T. lariang and the insect density with $\mathrm{R}$ value close to 1 . This means the increasing of insect density has significant effect on the increasing of the density of $T$. lariang. The increasing of insect density is proportional to the density of $T$. lariang population due to the need of feed of $T$. lariang. Insects provide a variety of nutrients for the needs of insectivore primates including protein, fat, carbohydrates, chitin, enegy, vitamins and minerals [28]. The distribution pattern of $T$. lariang is significantly influenced by the abundance of insects to fulfill their daily 
needs (feeding) in performing their daily activities. Habitats that have a high abundance of insects affect significantly the high spread of density. Abundance of feeding sources is a factor that affects the distribution and density of animal populations [29].

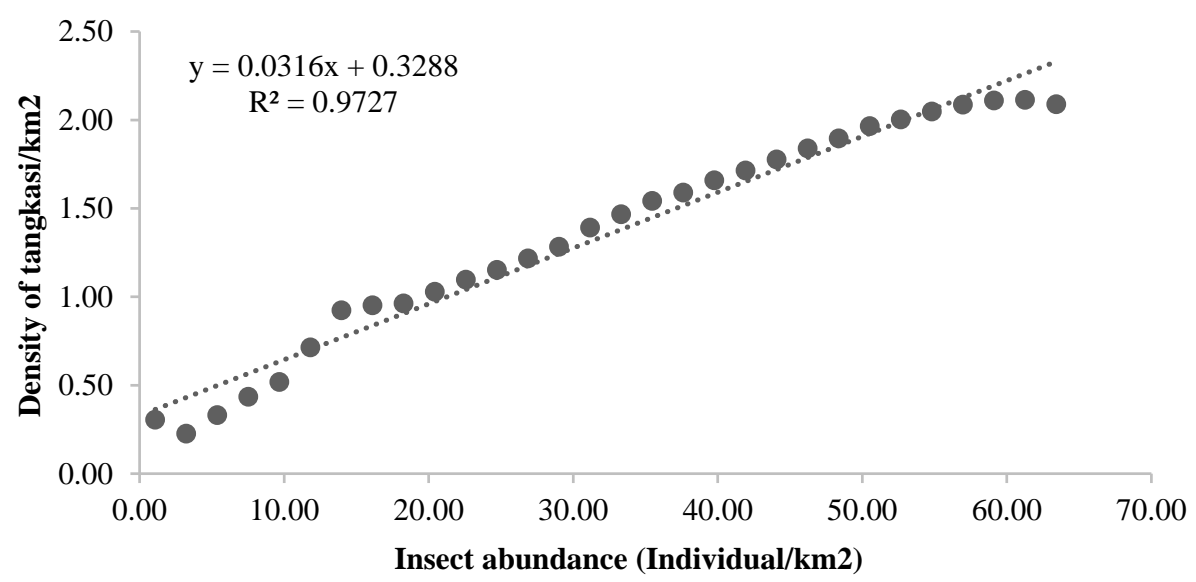

Figure 2. Correlation between the density of $T$. lariang and insect abundance

\subsubsection{Correlation of $T$. lariang density with physical factors}

Analysis of correlation between $T$. lariang density with physical factors consisted on the analysis of correlation between $T$. lariang density with temperature, humidity, altitude and slope. Air temperature and air humidity are closely correlated when the increasing of one unit of air temperature will affect the change of humidity. Each species of animals has different respond on different temperature and humidity values. Environmental temperature has a significant role in influencing the pattern of wildlife spatial distribution. So that temperature and humidity are included as limiting factors for wildlife survival. The results showed that the air temperature of $T$. lariang habitat was found in the ranges $22.5^{\circ} \mathrm{C}-27.5^{\circ} \mathrm{C}$ and humidity ranged between $75-$ $87 \%$ (Figures 3.a and 3.b). The T. lariang abundance seems to increase when the environmental temperature increases up to $27.5^{\circ} \mathrm{C}$ with $79 \%$ air humidity. T syrichta in captive breeding will die if the air temperature reaches below $18^{\circ} \mathrm{C}$. The preferred temperature ranges from $25^{\circ} \mathrm{C}$ to $30^{\circ} \mathrm{C}$, while the preferred humidity to prevent dryness of the skin is about $80 \%$ [29, 30]. The regression line form of $T$. lariang density with temperature is power shape with high $\mathrm{R}^{2}$ of $72 \%$. Since there is a very close correlation between the air temperature and air humidity $(\mathrm{r}=0.95)$, therefore, to simplify the model, only one variable would be selected, either humidity or temperature. The correlation between air temperature and humidity with T. lariang is quite high, larger than 0.7 so that air temperature and humidity have significant effect to the increasing of T. lariang abundance. This shows that temperature has significant impact to the abundance of T. lariang in Figure 3a).

The highest level of $T$. lariang abundance occurs in areas with altitude between 800-1000 masl (Figure 3.c) and will decrease along with the increase on altitude. The altitude of 2000 masl has the highest insect diversity and will decrease along with the increasing of altitude [31-33]. This is in line with the general theory of ecological changes, when altitude of the site increases, the temperature decreases, the density of flora is linearly decreased and the diversity of both flora and fauna decreases [33]. Another factor in decreasing the density of $T$. lariang is the increasing of altitude, the higher the altitude, the lower the insect species diversity, which represents the source of $T$. lariang feeding [33, 34]. The altitude also affects $T$. pumilus when the altitude of the site decreases the feed source, which affects its behavioral change, morphology and body size [31]. Regression analysis of the $T$. lariang density with the slope shows the $\mathrm{R}^{2}$ value of only $32.27 \%$ in Figure $3 \mathrm{~d}$. This shows that there is no significant effect of slope variation to the T. lariang density.

T. tarsier in Buton island was found at most on the slopes $>40 \%$ which belong to the category of very steep slopes [17]. Tarsius on Selayar Island and TWA Patunuang South Sulawesi are more commonly found on topographic ramps up to 20\% slopes [35] and T. fuscus in Bantimurung Bulusaraung National Park at low slopes ranging from $0-25 \%$ [34]. This study differs from the study of T. tarsier in Buton where the T. tarsier was more commonly found at the slopes steeper than $40 \%$ [17]. 


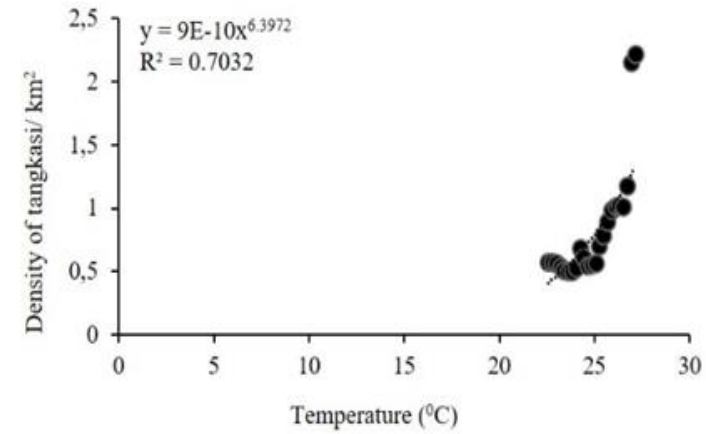

(a)

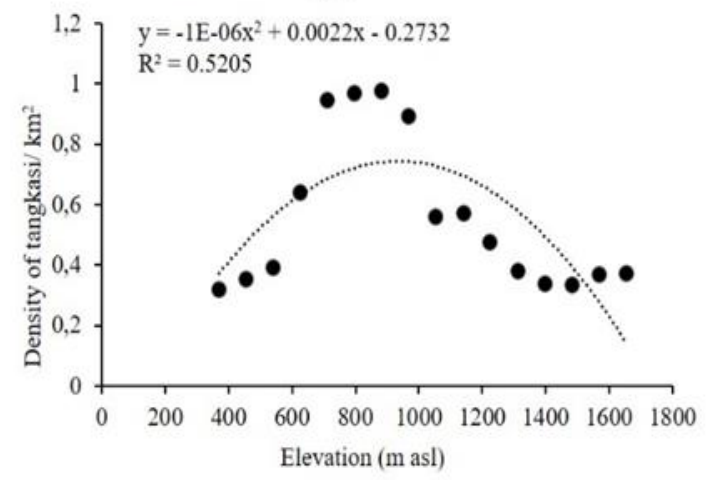

(c)

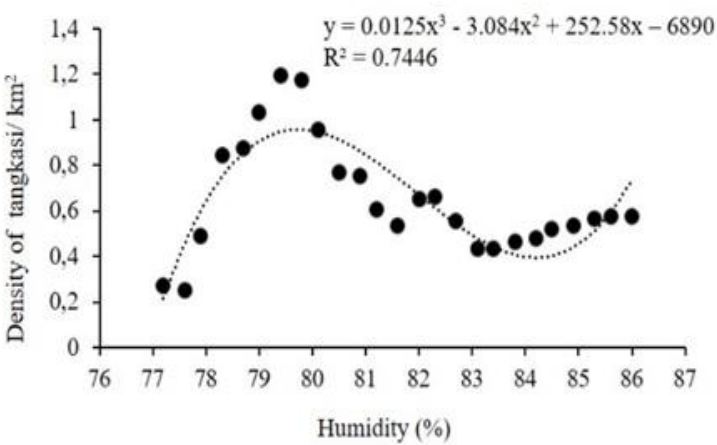

(b)

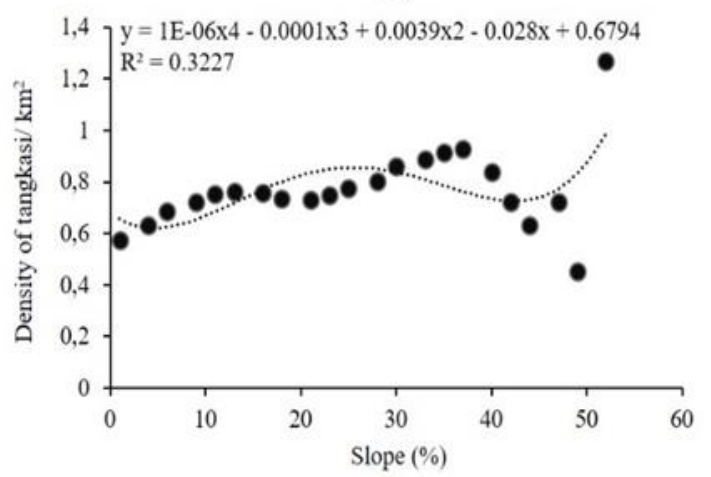

(d)

Figure 3. Correlation of $T$. lariang density with (a) temperature; (b) humidity; (c) elevation; (d) slope

\subsubsection{Correlation between density of $T$. lariang with human disturbance}

$T$. lariang is an animal that has different responses to human presence, depending on the types of contact and $T$. lariang's interaction with humans. For $T$. dianae located in Kamarora TNLL, high dense populations are mostly found in the areas with high disturbance $[1,36]$. This study examined three disturbance factors that affect the density of $T$. lariang, namely the distance from commercially utilized area, the distance from settlement and the distance from road. The regressions between $T$. lariang and distance from road, settlement, and commercial area show high coefficients of determination of $61.4 \%$; $60.7 \%$; and $79.9 \%$, respectively. The $\mathrm{R}^{2}$ value between $T$. lariang and all human disturbance factors is $>50 \%$, indicating that all factors influence the density of $T$. lariang. The $T$. lariang density also has a very close correlation with proximity from commercial area, in Figure 4.a, where the highest density was occurred at the $4000 \mathrm{~m}$ distance. The highest density of $T$. lariang was also found at the distance of 4000 from the settlement area in Figure 4.b and the highest abundance of $T$. lariang were found at the distance of $4000 \mathrm{~m}$ from the road in Figure 4.c. The maximum distance between $T$. lariang density and all three disturbance factors is indicated as the edge area, this is identified by the tendency of the dropping back density after the maximum density increases. In these areas, it is possible that human disturbances are not very high, have sufficient feed abundance and allow $T$. lariang to hide into the primary forest area. The size of the $T$. dianae group decreases with increasing levels of disturbance and $T$. pumilus has an increased abundance in line with the abundance of insects at the edge area $[1,31]$. 


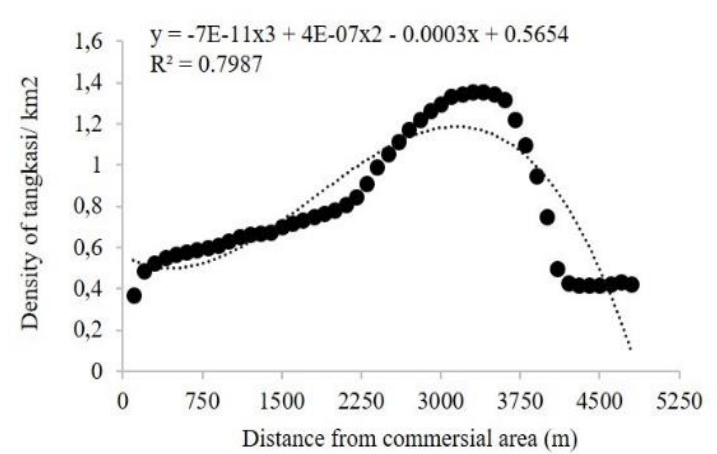

(a)

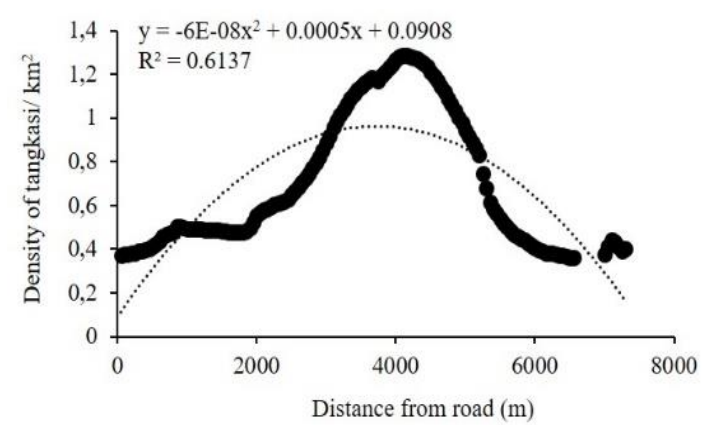

(c)

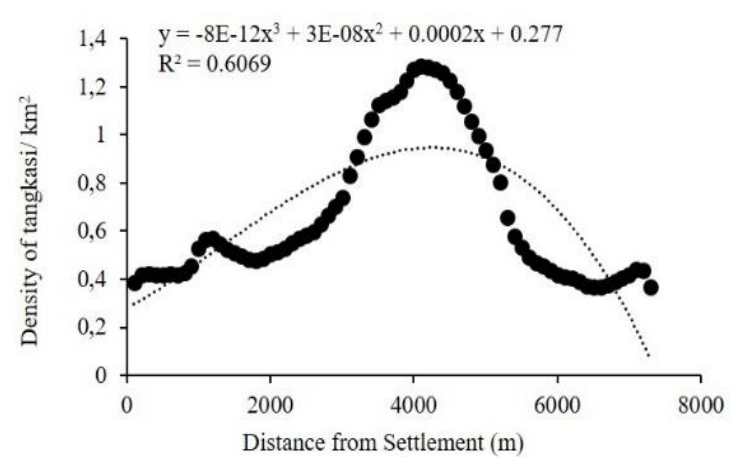

(b)

Figure 4. Correlation of $T$. lariang density with (a) commercial areas; (b) settlement areas;

(c) distance from road

\subsection{Selection of determinant variables}

This research uses 8 variables $\mathrm{X}$ as mentioned previously independent of $T$. lariang such as namely (a) abundance of insect (X1), (b) distance from road (X2), (c) distance from settlement (X3), (d) distance from commercial area (X4), (e) altitude (X5), (f) slope (X6), (g) temperature (X7), and (h) humidity (X8), while the dependent variable is the density of $T$. lariang (indicator Y). Table 2 shows that the highest correlation occurs between the density of $T$. lariang with the abundance of insects with a $\mathrm{R}^{2}$ value of $97.3 \%$. Except for slope (X6), there is a close correlation between density of $T$. lariang and affecting factor with $\mathrm{R}^{2}>50 \%(\mathrm{R}>0.7)$.

Table 2 Determination coefficient value among the variables

\begin{tabular}{|c|c|c|c|c|c|c|c|c|}
\hline \multirow{2}{*}{ Variables } & \multicolumn{8}{|c|}{ Determinant coefficient $\left(\mathrm{R}^{2}\right)(\%)$} \\
\hline & $\mathrm{Y}$ & $\mathrm{X}_{1}$ & $\mathrm{X}_{2}$ & $\mathrm{X}_{3}$ & $\mathrm{X}_{4}$ & $\mathrm{X}_{5}$ & $\mathrm{X}_{6}$ & $\mathrm{X}_{7}$ \\
\hline $\mathrm{X}_{1}$ & 97.3 & & & & & & & \\
\hline $\mathrm{X}_{2}$ & 61.4 & 31.4 & & & & & & \\
\hline $\mathrm{X}_{3}$ & 60.7 & 32.3 & 96.8 & & & & & \\
\hline $\mathrm{X}_{4}$ & 79.9 & 40.8 & 80.5 & 87.3 & & & & \\
\hline $\mathrm{X}_{5}$ & 52.1 & 22.3 & 58.9 & 73.0 & 67.0 & & & \\
\hline $\mathrm{X}_{6}$ & 32.3 & 3.6 & 11.5 & 12.5 & 9.3 & 2.3 & & \\
\hline $\mathrm{X}_{7}$ & 70.3 & 12.1 & 30.9 & 36.5 & 5.6 & 33.3 & 4.9 & \\
\hline $\mathrm{X}_{8}$ & 74.5 & 15.9 & 30.4 & 30.9 & 11.2 & 5.5 & 0.2 & 89.6 \\
\hline
\end{tabular}

Among independent variables, temperature (X7) and humidity (X8) have a quite high $\mathrm{R}^{2}$ value of $89.6 \%$. This relationship shows that the higher the temperature the lower the humidity. In addition, the distance from the road (X2), distance from the settlement (X3), and the distance from the commercially utilized area (X4) have a very high correlation, more than $80 \%$ (see table 2). Furthermore, for developing the T. lariang density class, into 2 or 3 classes, the clustering analysis was performed, where the class was grouped using complete linkage approach. The classification used several combinations that are related with the density of $T$. lariang (Y).The three types of combinations were examined, namely (1) all X variables were used, (2) three X variables, i.e., insect abundance (X1), distance from commercial area (X4), and temperature (X7), with Y. (3) 
The distance from the commercial area (X4) and the temperature (X7) with Y. Then variable combinations in each determinant variable was chosen based on accuracy value assessment.

\subsubsection{Classification of spatial distribution variable}

By using the clustering method with the complete linkage dendrogram, the spatial distribution of the T. lariang was classified into 2 dan 3 classes. Within all examined combination, the obtained accuracy assessment is summarized in Table 3. It is shown that the overall accuracy of 3 classes is very high (90\%). When the classes was merged into only 2 classes, the overall accuracy (OA) of the classes was even higher, i.e. $96 \%$, with 94\% producer's accuracy (PA) and 97\% user's accuracy (UA).

To avoid multicollinearity and simplify the clustering process, only $\mathrm{X} 1, \mathrm{X} 4$ and $\mathrm{X} 7$ were examined. When the independent variables were X1, X4 and X7 then the obtained overall accuracy was about $87 \%$. Furthermore, when the number of variable was reduced, where only the X4 and X7 were considered then the OA decreased to $83.5 \%$. This study recognized that the variable $\mathrm{X} 4$ and $\mathrm{X} 7$ provide much better accuracy as well as more practical implementation, in comparison with the use of the variable X1 alone. Although, the variable X1 alone provides an OA of 76.9\%. The use of variable X1 (insect abundance) would be more difficult due to the limitation of the insect abundance.

Table 3. Accuracy assessment using with 2 and 3 classes

\begin{tabular}{lcc} 
& Accuracy of 2 classes (\%) & Accuracy of 3 classes (\%) \\
\hline Variable all & & \\
OA & 96.2 & 90.0 \\
Avg PA & 94.4 & 89.3 \\
Avg UA & 97.7 & 89.0 \\
Variable X1, X4, X7 & & \\
OA & 96.6 & 86.7 \\
Avg PA & 97.4 & 85.7 \\
Avg UA & 95.8 & 91.7 \\
Variable X4, X7 & & \\
OA & 93.3 & 83.5 \\
Avg PA & 96.7 & 75.0 \\
Avg UA & 96.6 & 92.0 \\
Variable X1 & & \\
OA & 88.3 & 76.7 \\
Avg PA & 90.7 & 62.5 \\
Avg UA & 68.8 & 80.5 \\
\hline Information: Overall accuracy, Avg PA = average producers accuracy, Avg UA = average user accuracy
\end{tabular}

\section{CONCLUSION}

From the forgoing discussion, the study concludes that Tarsius lariang species has a clumped spatial distribution pattern. The clumped pattern of $T$. lariang is empirically influenced by some environmental factors. The most significant environmental factor affecting the density of T. lariang is insect abundance (X1), followed by distance to commercial area (X4), humidity (X8), temperature (X7), distance from the road (X2), distance to settlement (X3), and altitude (X5). These ones significantly affect $T$. lariang density with coefficients of determination $\left(\mathrm{R}^{2}\right)$ larger than $\geq 50 \%$. The slope variable (X6) does not affect the spatial pattern significantly. For classifying the spatial distribution of the T. lariang, the classification into 3 classes with all variables provides excellent accuracy of 90\% OA, 89.3\% PA, and 89.0\% UA. Meanwhile, analysis with X1, X4, and X7 provides $86.7 \%$ OA, $85.7 \%$ PA and $91.7 \%$ UA. The use of only X4 and X7 for density classification provides about $83.50 \%$ OA, $75.0 \%$ PA, and $92.0 \%$ UA.The variable X1 (insect abundance) is not recommended since the variable is technically impratical.

\section{REFERENCES}

[1] Merker S, Groves CP. 2006. Tarsius lariang: A New Primate Species from Western Central Sulawesi. International Journal Primatology. 27: 465-485.

[2] Merker S, Yustian I, Mühlenberg M. Responding to Forest Degradation: Altered Habitat Use by Dian's Tarsier Tarsius dianae in Sulawesi, Indonesia. Oryx. 2005; 39(02):189-195.

[3] [IUCN] International Union for Conservation of Nature and Natural Resources. Red list of threatened species.2014. http://www.iucnredlist.org/photos/2014.

[4] Kardika AD, Jaya INS, Puspaningsih N. Growth-s ite Quality Assessment of Nypa fruticans using Unmanned Aerial Vehicles Images: A case study in Kubu Raya Regency, West Kalimantan Province. Indonesian Journal of Electrical Engineering and Computer Science c 2018; 9(2): 502-511. 
[5] Muis H, Jaya INS, Saleh MB, Murtilaksono K. Information Required for Estimating theIndicator of Forest Reclamation Success in Ex Coal-Mining Area. Indonesian Journal of Electrical Engineering and Computer Science. 2016; 3(1): 182-193.

[6] Wahyuni S, Jaya INS, Puspaningsih N. Model for Estimating Above Ground Biomass ofReclamation Forest using Unmanned Aerial Vehicles. Indonesian Journal of Electrical Engineering and Computer Science (IJEECS). 2016; 4(3): 586-593.

[7] Jorge LAB, Garcia GJ. A Study of Habitat Fragmentation in South East Brazil Using Remote Sensing and Geographic Information Systems (GIS). Forest Ecology and Management. 1997; 98: 35-47.

[8] He HS, Mladenoff DJ, Radeloff VC, Crow TR. Integration of GIS Data and Classified Satellite Imagery for Regional Forest Assesment. Ecological Aplications. 1998; 8(4): 1072-1083.

[9] [ESRI] Environmental System Research Institute. GIS Best Practice Wildlife Management. 2010. https://www.esri.com/library/bestpractices/wildlife management.pdf.

[10] Jaya IN, Soewarno S, Sofyan W, Fadjar P. Inventarisasi Hutan dan Perencanaan Pengaturan Kelestarian Tegakan Hutan. Jakarta: Dirjen Bina Produksi Hutan-DEPHUT RI. 2010.

[11] Brockelman WY, Ali R. 1987. Methods of Surveying and Sampling Forest Primate Population. Di dalam: Mars CW dan Mittermeier RA (eds.). 1987. Primate Conservation in The Tropical Rain Forest. New York (US): Alan R. Liss, Inc. 22-62.

[12] Rinaldi D. 1992. Penggunaan Metode Triangle dan Concentration Count dalam Penelitian Sebaran dan Populasi Gibbon (HYLOBATIDAE). Media Konservasi 4(1): 9-12.

[13] O’Brien TG, Kinnard MF, Nurcahyo A, Iqbal M, and Rusmanto M. 2004. Abundance and distribution of sympatric gibbons in the treathened Sumatran rain forest. International Journal Primatology. 25(2): 267-284.

[14] Duma Y, Rosyid A, Rusyianton Y, Tanari M. 2010. Survey populasi Tarsius (T. dianae) di Toro Taman Nasional Lore Lindu Sulawesi Tengah. Di dalam: Umra, Yusran, Kassa S, Golar, Nurdin, Barus HN, Duma Y, Najib M, Jaya B, Nasmiah, Hatta U, Kasim A, Pattadungan YS et al. editor. Optimalisasi pengelolaan sumberdaya Provinsi Sulawesi Tengah melalui penelitian menuju Universitas Tadulako unggul dalam pengabdian kepada masyarakat tahun 2020; 2010 Okt 21; Palu, Indonesia. Yogyakarta (ID): Penerbit Pustaka Timur Yogyakarta. 169-175.

[15] Ludwig JA, Reynolds JF. Statiscal Ecology. A Primary on Methods and Computing. Canada: John Wiley \& Sons, Inc. 1988.

[16] Krebs CJ. Ecological Methodology. New York: Harper Collins Publisher Inc. 1989.

[17] Mansyur FI, Mustari AH, Prasetyo LB. Karakteristik Habitat Tarsius (Tarsius sp.) Berdasarkan Sarang Tidur di Hutan Lambusango Pulau Buton Provinsi Sulawesi Tenggara. Media konservasi. 2016; 21(2): 135-142.

[18] Kremsater L, Bunnell FL. Edge effects: Theory, Evidence and Implications to Management of Western North American Forests. In: Rochelle JA, Lehmann LA, Wisniewski J, editors.

[19] Malcolm JR. Edge Effects in Central Amazonian Forest Fragments. Ecology. 1994; 75: 2438-2445.

[20] Andrewartha HG, Birch LC. The Distribution and Abundance of Animals. Chicago: The University of Chicago Press. 1954.

[21] Forest Fragmentation: Wildlife and Management Implications. Leiden: The Netherlands; 1999. 117-153.

[22] Wirdateti, Dahrudin H. Pengamatan Pakan dan Habitat Tarsius spectrum di Cagar Alam Tangkoko-Batu Angus, Sulawesi Utara. Biodiversitas. 2006; 7(4): 373-377.

[23] Tarumingkeng RC. Dinamika Populasi: Kajian Ekologi Kuantitatif. Jakarta: Pustaka Sinar Harapan \& Universitas Kristen Krida Wacana. 1994.

[24] McGrew WC, The Other Faunivory: Primate Insectivory and Early Human Diet. In: Stanford CB, Bunn HT. Editor. Meate Eating and Human Evolution. Oxford: Oxford University Press; 2001:160-178.

[25] Sinaga W, Wirdateti, Iskandar E, Pamungkas J. Pengamatan Habitat Pakan dan Sarang Tarsius (Tarsius sp.) Wilayah Sebaran di Sulawesi Selatan dan Gorontalo. Jurnal Primatologi Indonesia. 2009; 6(2): 41-47.

[26] Charles-Dominique P, Ecology and Behaviour of Nocturnal Primates: Prosimians of Equatorial West Africa. New York: Columbia University Press. 1977.

[27] MacKinnon J, MacKinnon K. The Behavior of Wild Spectral Tarsiers. International Journal Primatology. 1980;1: 361-379.

[28] Gursky S, Tarsiformes. In: Campbell CJ, Fuentes A, MacKinnon KC, Bearder SK, Stumpf RM. Editor. Primates in Perspective. 2nd ed. New York: Oxford University Press; 2011: 79-90.

[29] Rotman JM, Raubenheimer D, Breyer MAH, Takahashi M, Gilbert CC. Nutritional Contribution of Insect to Primate Diets: Implications Primate Evolution. Journal of Human Evolution. 2014; 71(2014): 59-69.

[30] Embury AS. Husbandary Manual Philippine Tarsier (Tarsius syricta). Royal Melbourne Zoological Gardens. 1993.

[31] Grow NB. Altitudinal Effects on The Behavior and Morphology of Pygmy Tarsier (Tarsius pumilus) in Central Sulawesi, Indonesia. Dissertation. Texas: Texas A\&M University; 2013.

[32] Körner C. The Use of "Altitude" in Ecological Research. Trends in Ecology and Evolution. 2007; 22(11): 569-574.

[33] Hagvar S. Altitudinal Zonation of The Invertebrate Fauna on Branches of Birch (Betula pubescens). Norwegian Journal of Entomology. 1976; 23: 61-74.

[34] Amnur NA. Karakteristik Habitat Preferensial Tarsius (Tarsius tarsier) di Taman Nasional Bantimurung Bulusaraung, Maros, Sulawesi Selatan. Thesis. Bogor: Sekolah Pascasarjana Institut Pertanian Bogor. 2010.

[35] Qiptiyah M, Setiawan H. Kepadatan Populasi dan Karakteristik Habitat Tarsius (Tarsius spectrum) Dikawasan Pattunuang, Taman Nasional Bantimurung-Bulusaraung, Sulawesi Selatan. JPHKA. 2012; 9(4): 363371.

[36] Yustian I, Merker S, Supriatna J, Andayani N. Relative Population Density of Tarsius dianane in Man-Influenced Habitats of Lore Lindu National Park, Central Sulawesi, Indonesia. Asian Primatology Journal. 2008; 1(1):10-16. 